\title{
Effect of freezing pretreatment on the quality of osmotically extracted syrup from Citrus junos peel
}

\author{
Han-Sol Park, Dong-Seob Kim, Han-Soo Kim, Young-Guen Lee, Hun-Sik Chung* \\ Department of Food Science and Technology, Pusan National University, Miryang 50463, Korea
}

\section{동결 전처리가 유자과피 당절임 삼출액의 품질 특성에 미치는 영향}

\author{
박한솔 · 김동섭 · 김한수 · 이영근 · 정헌식* \\ 부산대학교 식품공학과
}

\begin{abstract}
In this study, we assessed the effect of freezing pretreatment on the quality of osmotically extracted syrup from Citrus junos peels. Sliced peels were frozen for 7 days at $-20^{\circ} \mathrm{C}$ or $-70^{\circ} \mathrm{C}$, mixed with sucrose and then stored for 40 days at $15^{\circ} \mathrm{C}$. Syrups were prepared from these mixtures after osmotic treatment. Non-frozen fruits were used as control. The initial freezing point of $C$. junos peels was $-4^{\circ} \mathrm{C}$. Nominal freezing times were 42 and 13 min for $-20^{\circ} \mathrm{C}$ and $-70^{\circ} \mathrm{C}$, respectively. The osmotically extracted syrup from the frozen peels was reddish brown while that of the untreated peels was yellow. The titratable acidity of the pretreated syrups was significantly higher than that of the untreated syrup, but clarity, vitamin $C$ content, and 1,1-diphenyl-2-picrylhydrazyl (DPPH) radical scavenging activity were considerably lower. The pretreated syrups showed no notable difference in color, titratable acidity, clarity, and DPPH activity. Furthermore, contents of soluble solids, phenolic compounds, and flavonoids were unaffected. These results suggest that freezing before osmotic extraction affects the quality, producing syrups with higher acidity, reddish brown color, and lower antioxidant activity.
\end{abstract}

Key words : Citrus junos, peel, freezing, osmotic extraction, syrup

\section{서 론}

유자나무(Citrus junos)는 귤속 식물 중 내한성과 내병성 이 비교적 강한 상록관목이며, 동아시아 지역이 원산지와 주 재배지이고, 그의 과실은 면역력 증진, 미백, 항산화, 항비만, 항암 및 항아토피 등의 효과를 가지는 것으로 알려 져 있다(Shin 등, 2008; Lee 등, 2009; Kim 등, 2010; Jo 등, 2012; Kim 등, 2014; Yang 등, 2015). 그러나 유자 과실은 껍질이 두껍고 종자가 많으며, 강한 산미와 고유한 향을 가져 직접 생식보다는 당절임 형태로 가공되고 있어 고부 가가치화와 소비확대를 위해서는 제품의 품질개선과 다
양화가 필요한 실정이다(Lee와 $\mathrm{Na}, 2012)$.

당절임 처리는 당의 삼투압을 이용하여 조직 내로부터 탈수와 유용성분 추출 및 미생물 생육을 억제함과 동시에 감미를 부여하는 방법으로 과실류와 약용작물로부터 고 형 절임물과 삼출액의 제조에 적용되고 있다. 당절임 처리 관련 연구결과로서, 인삼정과(절임물) 제조시 당의 종류에 따른 품질특성의 유의적 차이가 있으며(Song 등, 2010), 미숙복숭아의 당절임 처리시 설탕 대체 올리고당의 사용 은 절임물의 품질과 항산화능을 향상시키는 효과가 있고 (Jung 등, 2017), 유자 당절임 처리의 경우에서도 xylitol과 erythritol의 설탕 대체효과가 있음이 보고되었다(Yoon과

*Corresponding author. E-mail : hschung@pusan.ac.kr, Phone : +82-55-350-5352, Fax : +82-55-350-5359

Received 27 September 2019; Revised 30 October 2019; Accepted 19 November 2019.

Copyright (c) The Korean Society of Food Preservation.

This is an Open Access article distributed under the terms of the Creative Commons Attribution Non-Commercial License (http://creativecommons.org/licenses/by-nc/4.0) which permits unrestricted non-commercial use, distribution, and reproduction in any medium, provided the original work is properly cited. 
Kim, 2003). 또한, 마의 당절임 처리에서 당 농도, 온도와 시간의 최적조건 설정(Han 등, 2003)과 당유자 과실의 당 절임 처리에서 과실의 세절 방법에 따른 제품의 기호도 조사결과(Kim 등, 2007)가 보고된 바 있다. 이상과 같이 당절임 처리 조건 관련 연구는 다수 수행된 바 있으나 당절임 전처리에 관한 연구는 매실의 동결 전처리 효과 보고(Chung 등, 2013)를 제외하면 거의 찾아보기 힘든 현 실이다.

동결 처리는 빙결정을 형성하여 식품보존 기능을 가지 게 하나 조직파괴가 동반되는 문제점 있어 가능한 조직파 괴를 줄이려는 방향으로 많은 연구가 수행되었으나 오히 려 이러한 조직파괴를 유익하게 이용하고자 하는 연구도 보고된 바 있다. 즉, 동결 전처리가 매실의 건조속도와 착즙수율을 향상시키고, 당근 착즙액의 점도를 낮추고, 사과의 착즙수율을 증대시킨다고 하였다(Chung 등, 2010; Nadulski 등, 2014; Nadulski 등, 2016). 그리고 앞서 언급한 매실 당절임에서의 동결 전처리 효과(Chung 등, 2013)가 당절임의 공정개선과 삼출액의 성분 수율을 증대시킨 점 을 볼 때 유자 과피의 당절임에서도 동결 전처리의 효과가 있을 것으로 예상된다.

본 연구에서는 유자 과피의 활용성 증대를 위한 기술개 발의 방편으로 당절임 삼출공정에 동결 전처리의 적용 효과를 검토하고자, 동결온도를 달리하여 처리한 유자 과 피를 설탕 삼투 처리하여 얻은 삼출액의 이화학적 품질 특성을 비교 분석하였다.

\section{재료 및 방법}

\section{재료}

실험용 유자(Citrus junos) 과실은 11월 중순 경상남도 남해군 지역에서 수확한 것을 익일 배송 받아 크기와 표면 색도가 균일한 과실만 선별하고 과피와 과육을 분리한 후 과피만을 사용하였다.

\section{동결처리 및 당절임 삼출액 제조}

유자 과피를 과도로 8 등분하고 플라스틱 봉지로 포장한 다음 chest freezer(Ilshinbiobase Co., Yangju, Korea)에 넣고 $-20^{\circ} \mathrm{C}$ 나 $-70^{\circ} \mathrm{C}$ 에서 7 일간 동결처리 하였다. 이때 과피의 품온 변화는 온도센스(T-type thermocouple)를 과피의 기하 학적 중심에 위치시키고 thermometer(TM-947SD, Lutron Electronic Enterprise Co., Ltd., Taipei, Taiwan)를 사용하여 기록하였다. 동결처리 직후 시료와 비동결 대조구 시료 일정 량을 각 유리병에 넣고, 상부에 시료와 동량의 설탕 (CJ Cheiljedang Co., Incheon, Korea)을 넣은 다음 뚜껑으로 밀봉하고 $15^{\circ} \mathrm{C}$ 에서 40 일간 삼투처리 한 후 면포로 여과하 여 당절임 삼출액을 제조하였고 이를 분석용 시료로 사용
하였다.

\section{갈변도 및 투명도 측정}

갈변도는 spectrophotometer(UV1800, Shimadzu, Kyoto, Japan)를 사용하여 $420 \mathrm{~nm}$ 에서 light absorbance를 측정하 여 나타내었다. 투명도는 spectrophotometer(UV1800, Shimadzu)를 사용하여 $650 \mathrm{~nm}$ 에서 light transmittance를 측정 하여 나타내었다.

\section{색도 측정}

색도는 분광측색계(CM-5, Konika Minolta Inc., Tokyo, Japan)를 사용하여 투과색의 CIE L*, $\mathrm{a}^{*}, \mathrm{~b}^{*}, \mathrm{~h}^{\circ}, \mathrm{C}^{*}$ 값을 각각 측정하였다. $\mathrm{L}^{*}$ 값은 lightness를, $+\mathrm{a} *$ 와 $-\mathrm{a}$ *값은 redness와 greenness를, $+b^{*}$ 와 $-b^{*}$ 값은 yellowness와 blueness를 각각 나타낸다. $\mathrm{h}^{\circ}$ 값은 색상(red-purple: $0^{\circ}$, yellow: $90^{\circ}$, bluish-green: $180^{\circ}$, blue: $\left.270^{\circ}\right)$ 을 나타내고, $\mathrm{a}^{*}>0, \mathrm{~b}^{*}>0$ 이면 $\mathrm{h}^{\circ}=\tan ^{-1}\left(\mathrm{~b}^{*} / \mathrm{a}^{*}\right)$ 로, $\mathrm{a}^{*}<0, \mathrm{~b}^{*}>0$ 이면 $\mathrm{h}^{\circ}=180^{\circ}+\tan ^{-1}\left(\mathrm{~b}^{*} / \mathrm{a}^{*}\right)$ 으로 각각 계산된다.

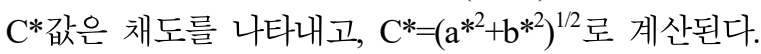

\section{가용성 고형분 함량 측정}

가용성 고형분 함량은 굴절계(Master, Atago Co., Tokyo, Japan)를 사용하여 측정하였다.

\section{적정산도 측정}

적정산도는 당절임 삼출액 시료 $5 \mathrm{~g}$ 을 취하고 여기에 증류수 $20 \mathrm{~mL}$ 를 가한 다음 $0.1 \mathrm{~N} \mathrm{NaOH}$ 용액으로 $\mathrm{pH}$ 8.2가 될 때까지 적정하여 소비된 $\mathrm{mL}$ 수를 citric acid로 환산하여 나타내었다.

\section{총페놀 함량 측정}

총페놀 함량은 당절임 삼출액 시료를 취해 Folinciocalteu법(Singleton과 Rossi, 1965)에 준하여 측정하였다. 즉, 시료액 일정량을 시험관에 취하고 여기에 Folinciocalteu reagent $2 \mathrm{~mL}$ 를 가한 다음 3 분간 정치하고 $10 \%$ $\mathrm{Na}_{2} \mathrm{CO}_{3}$ 용액 $2 \mathrm{~mL}$ 를 가하였다. 이 혼합액을 1 시간 동안 정치한 후 spectrophotometer(UV1800, Shimadzu)를 이용하 여 $760 \mathrm{~nm}$ 에서 흡광도를 측정하였고, 정량은 gallic acid 표준품으로 검량선을 작성하여 실시하였다.

\section{플라보노이드 함량 측정}

플라보노이드 함량은 Davis법(Davis, 1947)으로 측정하 였다. 즉, 당절임 삼출액 시료 일정량에 $99 \%$ diethylene glycol $5 \mathrm{~mL}$ 와 $4 \mathrm{~N} \mathrm{NaOH} 0.1 \mathrm{~mL}$ 를 가하고, $30^{\circ} \mathrm{C}$ 에서 10 분간 방치한 후 spectrophotometer(UV1800, Shimadzu)를 이용하여 420 $\mathrm{nm}$ 에서 흡광도를 측정하였고, 정량은 naringin 표준품을 사 용하여 검량선을 작성하여 실시하였다. 


\section{비타민 C 함량 측정}

비타민 C 함량 측정은 2,4-dinitrophenylhydrazine(DNP) 비색법(Roe와 Osterling, 1944)으로 행하였다. 즉, 당절임 삼출액 시료 일정량을 취하고, 여기에 $0.2 \%$ indophenol 2-3 방울 가하여 혼합하고 1 분간 방치한 후 $2 \%$ thiourea $2 \mathrm{~mL}$ 와 $2 \% \mathrm{DNP} 1 \mathrm{~mL}$ 를 가하고 $50^{\circ} \mathrm{C}$ 항온수조에서 1.5 시간 방치 하였다. 여기에 뷰렛으로 $85 \%$ sulfuric acid $5 \mathrm{~mL}$ 를 얼음물 속에서 서서히 첨가한 다음 상온에서 30 분간 방치한 후 $540 \mathrm{~nm}$ 에서 흡광도를 측정하였으며, L-ascorbic acid 표준 품으로 검량선을 작성하여 정량하였다.

\section{$\mathrm{DPPH}$ 유리기 소거능 측정}

1,1-Diphenyl-2-picrylhydrazyl(DPPH) radical scavenging activity는 Blois법(Blois, 1958)으로 측정하였다. 즉, 시료액 일정량에 $0.2 \mathrm{mmol} / \mathrm{L} \mathrm{DPPH}$ 용액 $2 \mathrm{~mL}$ 가하고 10 초간 강하게 진탕한 다음 30 분간 정치하고 spectrophotometer (UV1800, Shimadzu)를 이용하여 $517 \mathrm{~nm}$ 에서 흡광도를 측 정하였다. DPPH 유리기 소거능은 다음 식으로 계산하였 다.

$\mathrm{DPPH}$ 유리기 소거능(\%)

$=[1-($ 시료액의 흡광도/DPPH 용액의 흡광도 $) \times 100]$.

\section{통계처리}

실험결과는 3 회 반복실험의 평균 \pm 표준편차로 나타내었 고, IBM SPSS Statistics(23, IBM Corp., Armonk, NY, USA) 를 이용하여 분산분석과 Duncan's multiple range test $(\mathrm{p}<0.05)$ 를 실시하였다.

\section{결과 및 고찰}

\section{동결 중 유자 과피의 온도 변화}

동결 처리 중 유자 과피의 동결곡선은 Fig. 1 과 같다. 동결온도가 낮을수록 품온이 빠르게 감소되었으며, 동결 점이라고 하는 동결곡선 상에서 freezing plateau가 시작되 는 시점의 온도는 $4^{\circ} \mathrm{C}$ 로 관측되었다. 공칭동결시간 (nominal freezing time)은 초기 동결점에서 $10^{\circ} \mathrm{C}$ 만큼 감소

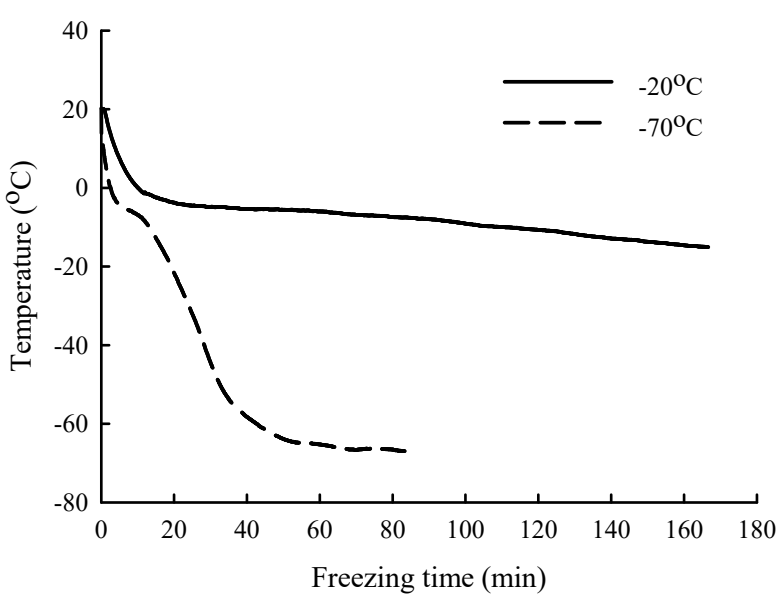

Fig. 1. Changes in the temperature of Citrus junos peel during the freezing process at $-20^{\circ} \mathrm{C}$ and $-70^{\circ} \mathrm{C}$.

하는데 걸리는 시간으로 정의되고 동결속도의 척도로 사 용되는데(IIR, 1986), $-20^{\circ} \mathrm{C}$ 동결구에서 42 분을, $-70^{\circ} \mathrm{C}$ 동결구에서 13 분을 각각 나타내어 $-70^{\circ} \mathrm{C}$ 동결구의 동결 속도가 상대적으로 약 3 배 정도 빠른 것으로 평가되었다.

\section{삼출액의 갈변도, 투명도 및 색도}

동결 처리 유무와 온도에 따른 유자 과피 당절임 삼출액 의 갈변도와 투명도는 Table 1 과 같다. 유자 과피 삼출액의 갈변도는 대조구보다 동결 처리구에서 유의적으로 높았 으나, 동결 처리 온도 $\left(-20^{\circ} \mathrm{C}\right.$ 와 $\left.-70^{\circ} \mathrm{C}\right)$ 간에는 유의적인 차이를 보이지 않았다. 투명도는 동결 처리구보다 대조구 에서 유의적으로 높았으며, 동결 처리구간에는 유의적인 차이를 보이지 않았다. 이러한 동결 처리에 따른 유자 과피 삼출액의 갈변도와 투명도의 결과는 동결에 의한 조직 손상 때문에 촉진되는 효소적 갈변(Tomas-Barberan과 Espin, 2001)과 조직의 연화와 분해(Anzaldua-Morales 등, 1999)에 기인된 것으로 생각된다. 이와 같은 결과로부터 동결 전처리는 유자 과피 당절임 삼출액의 갈변도와 탁도 를 높이는 효과가 있으나 동결온도의 영향은 없는 것으로 확인되었다.

동결 처리 유무와 온도에 따른 유자 과피 당절임 삼출액 의 색도 $\left(\mathrm{L}^{*}, \mathrm{a}^{*}, \mathrm{~b}^{*}, \mathrm{C}^{*}, \mathrm{~h}^{\circ}\right.$ 값 $)$ 를 측정한 결과는 Table 2 와

\section{Table 1. Browning index and clarity of osmotically extracted syrup from peel of Citrus junos in relation to freezing pretreatment}

\begin{tabular}{lccc}
\hline & \multicolumn{3}{c}{ Freezing pretreatment } \\
\cline { 2 - 4 } & Non-frozen & $-20^{\circ} \mathrm{C}$ & $-70^{\circ} \mathrm{C}$ \\
\hline Browning index (abs at $420 \mathrm{~nm})$ & $1.20 \pm 0.11^{\mathrm{b} 1)}$ & $2.00 \pm 0.10^{\mathrm{a}}$ & $2.03 \pm 0.26^{\mathrm{a}}$ \\
Clarity $(\%$ transmittance at $650 \mathrm{~nm})$ & $95.31 \pm 1.32^{\mathrm{a}}$ & $77.90 \pm 3.19^{\mathrm{b}}$ & $78.74 \pm 8.61^{\mathrm{b}}$ \\
\hline
\end{tabular}

\footnotetext{
${ }^{1)}$ Values represent the mean \pm standard deviation $(n=3)$. Means within each row followed by different letters are significantly different at $\mathrm{p}<0.05$.
} 
같다. 색도는 동결 처리 유무에 의한 영향을 받았으나 동결 온도의 영향을 받지 않은 것으로 나타났다. 색도 중 $\mathrm{L}^{*}$ 값은 동결 처리구가 대조구보다 유의적으로 낮았으며, $\mathrm{a}$ *값은 동결 처리구가 +5.4 를, 대조구가 -10.8 을 나타내었고, $\mathrm{b}^{*}$ 값은 동결 처리구가 대조구보다 유의적으로 높았다. $\mathrm{C}^{*}$ 값 과 $\mathrm{h}^{\circ}$ 값은 동결 처리구가 대조구보다 각각 높고 낮았다. 이상의 색도 결과를 볼 때, 유자 과피로 당절임 삼출을 행하기 전의 동결 처리는 갈변을 촉진하는 것으로 확인되 었으나 실험에 적용한 동결온도의 영향은 받지 않는 것으 로 나타났다. 이러한 동결 처리에 따른 삼출액의 갈변 증가 는 매실의 동결 처리 후 얻은 착즙액과 건조물의 갈변도를 높게 한 결과(Chung 등, 2010)와 유사하였지만, 매실의 당 절임에서 동결 전처리는 삼출액의 갈변도를 낮게 하였다 는 결과(Chung 등, 2013)와는 상반되었다. 이는 매실의 경 우 동결 처리구와 비처리구의 침출기간의 차이가 상이 했으며 이것이 동결처리 유무보다 더욱 크게 영향을 미쳤 기 때문인 것으로 생각된다(Chung 등, 2013).

\section{삼출액의 가용성 고형분 및 적정산도}

동결 전처리 유무 및 온도에 따른 유자 과피 당절임 삼출액의 가용성 고형분 함량과 적정산도를 측정한 결과 는 Table 3 과 같다. 가용성 고형분 함량은 실험구별 유의적 인 차이가 없이 $59{ }^{\circ} \mathrm{Brix}$ 정도를 보였다. 적정산도는 동결 전처리구간에는 유의적인 차이가 없이 평균 $175 \mathrm{mg} / 100$ $\mathrm{g}$ 이었으나 대조구의 경우 $114 \mathrm{mg} / 100 \mathrm{~g}$ 을 보여 동결 전처 리 유무별 유의적인 차이를 나타내었다. 이러한 동결 전처 리의 영향이 앞서 언급한 당절임 삼출액의 투명도 결과에 서와 일치하는 점을 볼 때 동결 처리구에서 유기산 삼출이 높은 것도 동결에 따른 조직 손상에 기인된 결과로 여겨지 고, 매실의 당절임 삼출의 경우에서 동결 전처리가 적정산 도를 높였다는 결과(Chung 등, 2013)와 유사하였다. 이로 써 유자 과피의 당절임 삼출에 있어 동결 전처리는 삼출액 의 적정산도를 증가시키는 효과를 가지나 동결온도의 영 향은 크지 않는 것으로 확인되었다.

\section{삼출액의 총페놀, 플라보노이드 및 비타민 C 함량}

동결 전처리에 따른 유자 과피 당절임 삼출액의 총페놀, 플라보노이드 및 비타민 $\mathrm{C}$ 함량을 측정한 결과는 Table 4에 나타내었다. 총페놀 및 플라보노이드 함량은 동결처 리 유무와 온도에 따른 유의적인 차이를 보이지 않았고, 평균 $731 \mathrm{mg} / 100 \mathrm{~g}$ 과 $169 \mathrm{mg} / 100 \mathrm{~g}$ 을 각각 나타내었다. 이로써 동결 전처리는 유자 과피에 함유된 총페놀과 플라 보노이드의 당절임 삼출에 영향을 미치지 않는 것으로 확인되었다. 이러한 결과는 유자 과실에 함유된 대표적인 플라보노이드인 naringin과 hesperidin이 과피 중 다공질 구조인 내피에 다량 들어 있어(Moon 등, 2015) 내피의 구조적 특성상 동결손상을 받지 않은 것이 하나의 원인인 것으로 생각된다.

Table 2. Color values of osmotically extracted syrup from peel of Citrus junos in relation to freezing pretreatment

\begin{tabular}{|c|c|c|c|c|}
\hline & & \multicolumn{3}{|c|}{ Freezing pretreatment } \\
\hline & & Non-frozen & $-20^{\circ} \mathrm{C}$ & $-70^{\circ} \mathrm{C}$ \\
\hline \multirow{5}{*}{$\begin{array}{l}\text { Color } \\
\text { value }\end{array}$} & $\mathrm{L}^{*}$ & $98.38 \pm 0.12^{\mathrm{al})}$ & $81.30 \pm 2.95^{b}$ & $80.81 \pm 1.99^{\mathrm{b}}$ \\
\hline & $a^{*}$ & $-10.77 \pm 0.30^{b}$ & $5.09 \pm 2.71^{\mathrm{a}}$ & $5.75 \pm 2.11^{\mathrm{a}}$ \\
\hline & $b^{*}$ & $34.13 \pm 1.81^{\mathrm{b}}$ & $55.68 \pm 3.84^{\mathrm{a}}$ & $55.95 \pm 1.09^{\mathrm{a}}$ \\
\hline & $\mathrm{C}^{*}$ & $35.79 \pm 1.82^{\mathrm{b}}$ & $55.95 \pm 4.04^{\mathrm{a}}$ & $56.27 \pm 1.31^{\mathrm{a}}$ \\
\hline & $\mathrm{h}^{\circ}$ & $107.52 \pm 0.40^{\mathrm{a}}$ & $84.89 \pm 2.51^{\mathrm{b}}$ & $84.16 \pm 2.00^{\mathrm{b}}$ \\
\hline
\end{tabular}

${ }^{1)}$ Values represent the mean \pm standard deviation $(\mathrm{n}=3)$. Means within each row followed by different letters are significantly different at $\mathrm{p}<0.05$.

Table 3. Soluble solid content and titratable acidity of osmotically extracted syrup from peel of Citrus junos in relation to freezing pretreatment

\begin{tabular}{lccc}
\hline & \multicolumn{3}{c}{ Freezing pretreatment } \\
\cline { 2 - 4 } & Non-frozen & $-20^{\circ} \mathrm{C}$ & $-70^{\circ} \mathrm{C}$ \\
\hline Soluble solid content ( ${ }^{\circ}$ Brix) & $59.07 \pm 0.06^{\mathrm{a} 1)}$ & $59.33 \pm 0.42^{\mathrm{a}}$ & $59.37 \pm 0.23^{\mathrm{a}}$ \\
Titratable acidity $(\mathrm{mg} / 100 \mathrm{~g})$ & $114.09 \pm 21.45^{\mathrm{b}}$ & $184.14 \pm 23.18^{\mathrm{a}}$ & $165.79 \pm 7.96^{\mathrm{a}}$ \\
\hline
\end{tabular}

\footnotetext{
${ }^{1)}$ Values represent the mean \pm standard deviation $(\mathrm{n}=3)$. Means within each row followed by different letters are significantly different at $\mathrm{p}<0.05$.
} 
Table 4. Phenolic compounds, flavonoids, vitamin C, and DPPH radical scavenging activity of osmotically extracted syrup from peel of Citrus junos in relation to freezing pretreatment

\begin{tabular}{cccc}
\hline & \multicolumn{3}{c}{ Freezing pretreatment } \\
\cline { 2 - 4 } & Non-frozen & $-20^{\circ} \mathrm{C}$ & $-70^{\circ} \mathrm{C}$ \\
\hline Phenolic compounds $(\mathrm{mg} / 100 \mathrm{~g})$ & $752.44 \pm 26.77^{\mathrm{a})}$ & $714.23 \pm 25.04^{\mathrm{a}}$ & $725.80 \pm 19.64^{\mathrm{a}}$ \\
Flavonoids $(\mathrm{mg} / 100 \mathrm{~g})$ & $152.75 \pm 1.05^{\mathrm{a}}$ & $178.24 \pm 16.99^{\mathrm{a}}$ & $176.34 \pm 13.18^{\mathrm{a}}$ \\
Vitamin C (mg/100 g) & $259.38 \pm 20.53^{\mathrm{a}}$ & $170.59 \pm 44.88^{\mathrm{b}}$ & $191.38 \pm 29.29^{\mathrm{b}}$ \\
DPPH radical scavenging activity $(\%)$ & $39.79 \pm 4.81^{\mathrm{a}}$ & $13.45 \pm 0.17^{\mathrm{c}}$ & $21.05 \pm 0.36^{\mathrm{b}}$ \\
\hline
\end{tabular}

${ }^{1)}$ Values represent the mean \pm standard deviation $(\mathrm{n}=3)$. Means within each row followed by different letters are significantly different at $\mathrm{p}<0.05$.

비타민 $\mathrm{C}$ 함량은 대조구가 $259 \mathrm{mg} / 100 \mathrm{~g}$ 을 보여 동결 처리구보다 유의적으로 높은 함량을 보였으나 동결 처리 구 간에는 유의적인 차이가 없이 평균 $181 \mathrm{mg} / 100 \mathrm{~g}$ 을 보였다. 이는 동결에 따른 조직 손상 결과 발생하는 비타민 $\mathrm{C}$ 의 삼출량의 증가보다는 산화에 의한 손실량이 더 많은 것에 기인된 결과로 여겨진다. 이로써 동결 전처리는 유자 과피로 얻은 당절임 삼출액의 비타민 $\mathrm{C}$ 함량을 감소시키 는 것으로 확인되었다.

\section{삼출액의 DPPH 유리기 소거능}

동결 전처리 유무 및 온도에 따른 유자 과피 당절임 삼출액의 항산화 활성을 DPPH 유리기 소거능으로 측정한 결과는 Table 4에 나타내었다. DPPH 유리기 소거능은 대 조구가 동결처리구보다 유의적으로 높았으며, 동결처리 구간에는 $-70^{\circ} \mathrm{C}$ 구가 $-20^{\circ} \mathrm{C}$ 구보다 약간 높은 것으로 나 타났다. 이로써 동결 전처리는 유자 과피 당절임 삼출액의 항산화능을 저하시키는 것으로 확인되었다. 이는 앞서 언 급한 비타민 C 함량(Table 4)과 연관성이 있는 것으로 생각 된다.

이상의 결과로부터 유자 과피의 당절임 전 동결처리는 삼출액의 유기산 함량을 높이지만 탁도와 갈변도를 높이 고 비타민 $\mathrm{C}$ 함량과 항산화능을 낮추는 것으로 나타났다. 이러한 효과의 동결온도별 차이는 보다 저온 동결에서 다소 높은 수준을 보인 항산화능을 제외하고는 나타나지 않았다. 따라서 유자과피를 이용한 당절임 삼출액 제조공 정에서 동결 전처리 단용 기술은 장점보다 단점이 많아 유용성이 낮은 것으로 확인되었으며, 차후 병용 기술의 적용과 장점 극대화를 위한 연구가 필요하다고 생각된다.

\section{요 약}

유자 과실의 활용성을 증대시키기 위한 일환으로 과피 당절임 삼출액 제조 및 동결 전처리가 품질특성에 미치는 영향을 조사하였다. 유자 과피를 세절하고 $-20^{\circ} \mathrm{C}$ 나 $-70^{\circ} \mathrm{C}$
에서 7일간 동결처리 및 무처리한 후 동량의 설탕을 가하고 $15^{\circ} \mathrm{C}$ 에서 40 일간 절임 처리하여 삼출액을 제조하였다. 유 자 과피의 동결점은 $-4{ }^{\circ} \mathrm{C}$ 이었고, 공칭동결시간은 $-20^{\circ} \mathrm{C}$ 와 $-70^{\circ} \mathrm{C}$ 에서 42 분과 13 분으로 각각 측정되었다. 유자 과피 삼출액의 색은 동결 처리구에서 적갈색을, 무처리구 에서 황색을 각각 나타내었다. 투명도는 동결온도에 따른 차이 없이 동결 처리구가 무처리구보다 유의적으로 낮은 값을 보였다. 적정산도는 동결온도의 영향 없이 동결 처리 구가 무처리구보다 유의적으로 높은 수준을 보였으나, 가 용성 고형분, 총페놀 및 플라보노이드 함량은 동결 처리 유무에 따른 유의적인 차이를 보이지 않았다. 반면에 비타 민 C 함량과 $\mathrm{DPPH}$ 유리기 소거능은 무처리구보다 동결 처리구에서 유의적으로 낮음을 보였다. 이로써 유자 과피 의 당절임에서 동결 전처리는 동결온도에 따른 차이 없이 삼출액의 품질 특성에 영향을 미치며 특히, 유기산 삼출수 율은 높이지만 갈변은 촉진하고 항산화능은 낮추는 것으 로 확인되었다.

\section{감사의 글}

이 논문은 부산대학교 기본연구지원사업(2년)에 의하 여 연구되었음.

\section{Conflict of interests}

The authors declare no potential conflict of interest.

\section{ORCID}

Hun-Sik Chung https://orcid.org/0000-0003-1990-9575

\section{References}

Anzaldua-Morales A, Brusewitz GH, Anderson JA. Pecan 
texture as affected by freezing rates, storage temperature, and thawing rates. J Food Sci, 64, 332-335 (1999)

Blois MS. Antioxidant determination by the use of a stable free radical. Nature, 181, 1199-1200 (1958)

Chung HS, Kim HS, Lee YG, Seong JH. Effects of freezing pretreatment on juice expression and drying characteristics of Prunus mume fruit. Korean J Food Preserv, 17, 507-512 (2010)

Chung HS, Kim DS, Kim HS, Lee YG, Seong JH. Effect of freezing pretreatment on the quality of juice extracted from Prunus mume fruit by osmosis with sucrose. LWT-Food Sci Technol, 54, 30-34 (2013)

Davis WB. Determination of flavanones in citrus fruits. Anal Chem, 19, 476-478 (1947)

Han JY, Hwang SH, Youn KS, Kim NW, Shin SR. Optimization for the sugaring process of Yam for snack food using response surface methodology. Korean J Food Preserv, 10, 320-325 (2003)

IIR. Recommendation for the Processing and Handling of Frozen Foods, 3th ed, International Institute of Refrigeration, Paris, France, p 32-39 (1986)

Jo GS, Hwang IT, Yun BG, Suh JK. Stability verification and anti-atopy efficacy on essential oil of Yuzu (Citrus junos Siebold ex Tanaka). Korean J Hort Sci Technol, 30, 58-59 (2012)

Jung KM, Choi MA, Park SI. Effect of oligosaccharides on quality characteristics and antioxidant activities of Prunus persica Batsch var. davidiana Max. preserved in sugar. Culi Sci Hos Res, 23, 163-172 (2017)

Kim DS, Kim DH, Oh MJ, Lee KG, Kook MC, Park CS. Antiaging and whitening activities of ethanol extract of Yuza (Citrus junos Sieb ex Tanaka) by-product. J Soc Cosmet Scientists Korea, 36, 137-143 (2010)

Kim TW, Kim KK, Kang YH, Kim DJ, Choe M. Fatty acid analysis and regulatory effects of citron (Citrus junos Sieb. ex Tanaka) seed oil on nitric oxide production, lipid accumulation, and leptin secretion. J Nutr Health, 47, 221-228 (2014)

Kim YJ, Moon JY, Kim JH, Kim HG, Kim JH, Kim S. Effects of mixing method and storage period of Dangyujasugar mixture on customer preferences for Dangyuja-tea. Korean J Food Preserv, 14, 160-164 (2007)

Lee $\mathrm{YH}, \mathrm{Na} \mathrm{JH}$. Citron tea exports state and quality standardization. Food Sci Ind, 45, 44-54 (2012)

Lee YJ, Hwang IG, Joung EM, Kim HY, Park ES, Woo KS, Jeong HS. Physiological activity and antiproliferation effects of citron seed extracts on cancer cells. J Korean Soc Food Sci Nutr, 38, 1672-1678 (2009)

Moon SH, Assefa AD, Ko EY, Park SW. Comparison of flavonoid contents and antioxidant activity of Yuzu (Citrus junos Sieb. ex Tanaka) based on harvest time. Kor J Hort Sci Technol, 33, 283-291 (2015)

Nadulski R, Grochowicz J, Sobczak P, Kobus Z, Panasiewicz M, Zawislak K, Mazur J, Starek A, Zukiewicz-Sobczak W. Application of freezing and thawing to carrot (Daucus carota L.) juice extraction. Food Bioprocess Tech, 8, 218-227 (2014)

Nadulski R, Kobus Z, Wilczynski K, Zawislak K, Grochowicz $\mathrm{J}$, Guz T. Application of freezing and thawing in apple (Malus domestica) juice extraction. J Food Sci, 81, 2718-2725 (2016)

Roe HJ, Osterling MJ. The determination of dehydroascorbic acid and ascorbic acid in plant tissues by the 2,4dinitrophenylhydrazine method. J Biol Chem, 152, 511517 (1944)

Shin JH, Lee SJ, Seo JK, Cheon EW, Sung NJ. Antioxidant activity of hot-water extract from Yuza (Citrus junos Sieb ex Tanaka) peel. J Life Sci, 18, 1745-1751 (2008)

Singleton VL, Rossi JA. Colorimetry of total phenolics with phosphomolybdic-phosphotungstic acid regents. Am J Enol Vitic, 16, 144-158 (1965)

Song MR, Kim MR, Kim HH, Chu S, Lee KS. Quality characteristics of ginseng Jung Kwa obtained by different sugar treatments. J Korean Soc Food Sci Nutr, 39, 999-1004 (2010)

Tomas-Barberan FA, Espin JC. Phenolic compounds and related enzymes as determinants of quality in fruits and vegetables. J Sci Food Agric, 81, 853-876 (2001)

Yang J, Jeon H, You YH, Kim JY, Choi HK, Choi KC, Jun WJ, Yoon HG. Citrus ethanol extracts promotes innate immune response by activating NF- $\kappa \mathrm{B}$. J Korean Soc Food Sci Nutr, 44, 1256-1263 (2015)

Yoon JY, Kim HS. Effect of xylitol and erythritol on the quality characteristics of Yuza tea. Korean J Soc Food Cookery Sci, 19, 737-744 (2003) 